\section{Cleansing river due for cleaning}

New Delhi

INDIA's holy river Ganges, which has been washing away the sins of devout Hindus for centuries, is itself to have a clean-up. The Indian government has set a five-year deadline for the first phase of cleaning the $2,500-\mathrm{km}$ river, at a cost of $£ 180$ million. The river carries 468,000 million cubic metres of water a year, a quarter of the country's surface water.

The task has been assigned to the newly formed Ganga Authority, headed by Prime Minister Rajiv Gandhi himself. The eight other members include planning and environment ministers of the central government and chief ministers of three of the eight states through which the Ganges flows. There is also a 17 -member steering committee under the chairmanship of environment secretary Dr T.N. Koshoo.

Pollution of the Ganges starts at Hardwar, where it enters the plains of Uttar Pradesh, $350 \mathrm{~km}$ from its source in Gangotri in the Himalayas. From Hardwar to Calcutta, the whole of the river has been declared by the Central Pollution Control Board (CPCB) as unfit even for bathing, and unsuitable for drinking without massive treatment. The board says the water has become so saline and so contaminated with toxic heavy metals that some parts of the Ganges basin are now infertile and the groundwater is polluted.

The Ganga Authority aims to restore the water quality under a plan drawn up by CPCB. Dr Nilay Choudhuri, CPCB's chairman, says that 80 per cent of the pollution is caused by raw sewage discharged directly into the river from 100 cities on its banks. The rest is caused by untreated effluent, wallowing and bathing of cattle, pesticide and fertilizer run-off and incompletely cremated dead bodies.

Apart from Hardwar, the most polluted places are Benaras, Kannauj, Allahabad, Benaras have become addicted to opium in in Hardwar. river will reduce pollution of the Ganges by 75 per cent according to Dr Koshoo. Twenty-seven cities with populations of more than 100,000 dump 900 million litres of municipal waste each day. The plan is to renovate existing sewerage systems and pumping stations and to build new drains Resource Recycling Units (RRU), where sewage will be digested to produce methane gas that will generate electricity. The residue will be sold as manure. Liquid remnants will be cleansed by biological aerators and the water produced will be used for irrigation and for growing algae and fish for sale.

According to Choudhuri, each RRU serving a population of 100,000 is expected to make an annual profit of $£ 850,000$, a sufficient incentive for private companies to take over the operation of the units after they have been built with government funds. In the second phase, the plan will be extended to the remaining 63 cities, and community cattle-sheds will be set up to collect animal wastes for processing at RRUs.

Unlike the Thames or the Danube, the cleaning up of the river Ganges is complicated by the fact that it is a sacred river to the Hindus. Millions of pilgrims immerse themselves in the river during festivals such as the Kumbha Mela and return home with a vessel filled with Ganges water.
Patna, Calcutta and Kanpur, where the Ganges water is thick and turbid for $10 \mathrm{~km}$ because of effluent from tanneries, textile mills and chemical plants. Monkeys in wastes discharged from a nearby factory making morphine from opium. On two occasions, the Ganges has caught fire because of oily effluent from a refinery in Barauni and discharges from a foundry forge plant

Stopping the discharge of sewage into the to divert the wastes to what are called

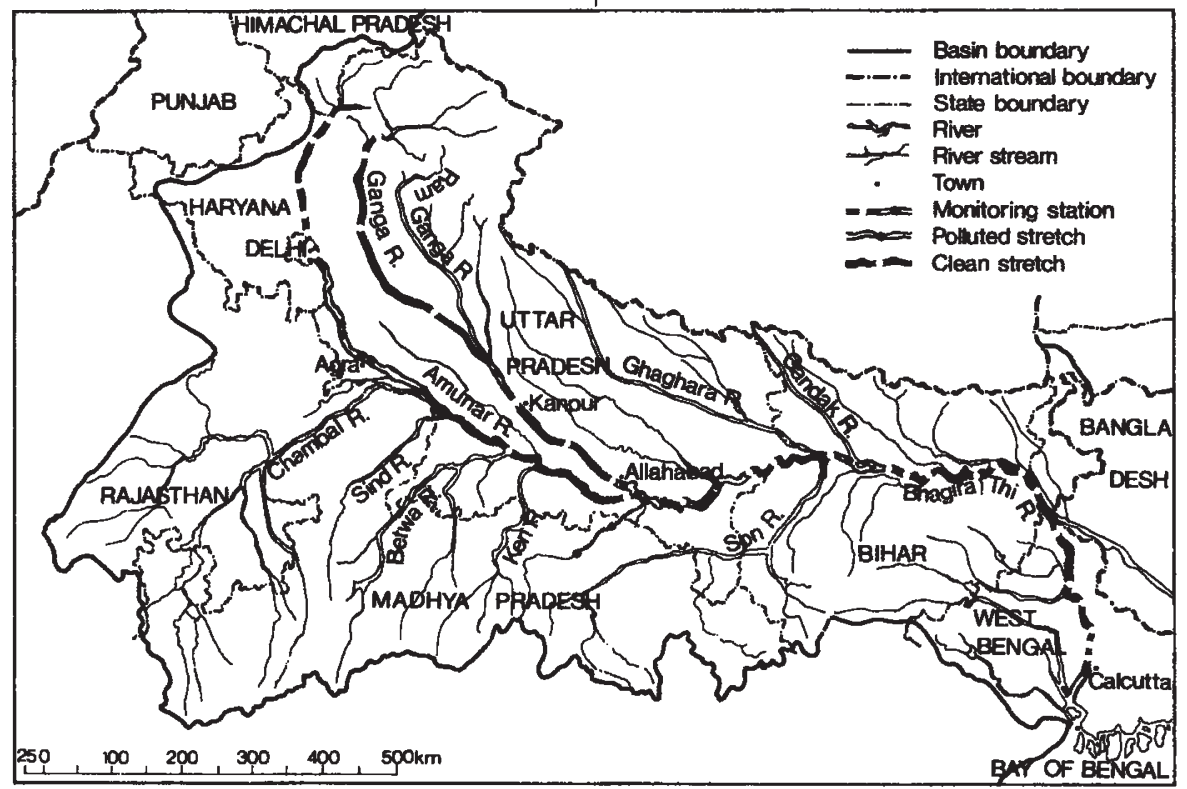

Choudhuri says that a mobile laboratory found 10,500 coliform counts in $100-\mathrm{ml}$ samples taking during a Kumba Mela in Allahabad. In Hardwar, 17.5 million litres of human and industrial waste pour daily from five drains, one of which is just upstream from where 10,000 people bathe every day and a million bathe during the Kumba Mela. At Benaras, 70,000 bathe daily in water that has been turned into an open sewer with the outfall of 120 million litres a day of sewage from 66 drains. Cremation in Benaras is the wish of every Hindu, so 400 half-burnt bodies float in the river on any day, and 9,000 cattle are thrown in each year. It is intended that electric crematoria will be built at several places along the river bank.

Even more alarming is the fact that the alluvial soil in the Ganges basin is showing signs of salinity in the state of Haryana, alkalinity in western Uttar Pradesh, acidity in West Bengal and calcareousness in north Bihar. Irrigation of Ganges water adds 17 million tonnes of salt a year to the soil, according to $\mathrm{CPCB}$. The Ganges basin receives 3,000 tonnes of pesticides a year and one-third of all the fertilizer used in India.

K.S. Jayaraman

\section{Polio eradication}

\section{Washington}

A PLAN to eradicate poliomyelitis from the Americas by the year 1990 has been announced by the Pan-American Health Organization (PAHO). PAHO believes the goal can be achieved by using its staff and volunteers to coordinate separate national efforts to encourage immunization.

The total cost of eradicating polio from North and South America is estimated at $\$ 100$ million: much of the infrastructure required is, however, already in place and only about $\$ 30$ million will be needed in aid from developed countries, much of which is already committed. Since 1977, when the World Health Organization instituted an expanded immunization programme to fight several common infectious diseases, the incidence of polio in the Americas has fallen from around 2,300 cases a year to 489 cases in 1984.

Dr Carlyle Guerra de Macedo, director of PAHO, says that 75 per cent of those under one year old in the Americas are now immunized against polio; before the expanded programme started, the figure was 25 per cent. The new plan will concentrate on surveillance and on training health workers to implement vaccination schemes. While admitting that the goal will not be easily achieved, Guerra de Macedo pointed out that the Americas were the first region of the World Health Organization to succeed in eliminating smallpox. The polio virus, like the smallpox virus, cannot survive for long periods outside a host and there is no animal reservoir. Total world elimination of polio is therefore a realistic goal. Tim Beardsley 